\title{
THREATS OF FORCE: INTERNATIONAL LAW AND STRATEGY
}

\section{Dr Francis Grimal, Routledge 2012, ISBN-13: 978-0415609852, Price $£ 70.40 \mathrm{hb}$}

\section{Peter Slinn ${ }^{*}$}

Dr Grimal's monograph on the law of armed conflict relating to threats of force, is a significant contribution to the literature. It ventures along one of the most perilous corridors of uncertainty in modern international law, and attempts with commendable courage to set the legal issues in the context of modern international relations. As Professor Breau writes in her Foreword, the existing literature concentrates overwhelmingly on the actual use of force, and there is little academic analysis of the meaning and significance of the threat of force in terms of the reference in article 2(4) of the United Nations Charter, to the duty of all members to 'refrain in their international relations from the threat or use of force against the territorial integrity or political independence of any state'. In deconstructing article 2(4), Dr Grimal draws attention to the use of the word 'refrain', rather curiously observing that 'refrain' is not the strongest adjective (sic). However, one can sympathise with the author's observation that threat categorisation is an inaccurate and imprecise science, depending more on context than anything else. Dr Grimal proceeds to consider what can be gleaned from the jurisprudence of international and national courts and tribunals and the interpretation offered in the practice of United Nations organs. He concludes that the existing jurisprudence gives inadequate guidance on what constitutes a threat of force. However, he also concludes that neither the General Assembly nor the Security Council tolerates threats to force.

The chapter on threat theory ends with the interesting proposition that the 'Just War Theory' lens may give greater guidance, in terms of establishing the lawfulness of a particular action and whether a threat may be tolerated, if it is designed to uphold some higher purpose. Presumably an example would be a threat to use force on humanitarian or similar grounds. Such threats appear to have become part of the currency of international relations in the twenty-first

\footnotetext{
* Dr Peter Slinn, Adjunct Professor of Law, University of Notre Dame (London Campus)
} 


\section{BOOK REVIEW}

century, so Dr Grimal's analysis is of particular contemporary relevance. Dr Grimal gives specific treatment to the issue of nuclear proliferation as a threat of force in the context of Iran and North Korea, although the latter's latest antics took place after Dr Grimals's work had gone to press.

Dr Grimal concludes by suggesting a reformulation of article 2(4) based on the Caroline test, so that the threat of force is only permitted for the purposes of self-defence in response to an unlawful act. If international law permits the use of force in self-defence, then logically the same should apply to threats. Presumably, given the practical difficulties in the way of any amendment of the Charter itself, the only hope of implementing Dr Grimal's proposal would be by way of an interpretative declaration on the lines of the 1970 Friendly Relations Declaration.

Dr Grimal's book contains a useful appendix of tables of relevant General Assembly and Security Council Resolutions and particularly comprehensive US style footnotes. The argument is clearly presented and, as Professor Breau suggests in her Foreword, is accessible to both students and scholars of international law and of international politics. International lawyers trespass into the field of international relations theory at their peril, but the legal study of the use or threat of force can only be understood in the wider political context, as current events in Syria and other parts of the Middle East illustrate only too clearly. Dr Grimal is to be commended for a thought-provoking and scholarly contribution to the debate. 